\title{
State of green technologies in South Africa
}

AUTHOR:

Roseanne Diab ${ }^{1}$

\section{AFFILIATION:}

${ }^{1}$ Academy of Science of South Africa, Pretoria, South Africa

\section{CORRESPONDENCE TO:}

Roseanne Diab

\section{EMAIL:}

roseanne@assaf.org.za

\section{POSTAL ADDRESS:}

PO Box 72135, Lynnwood Ridge 0040, Pretoria, South Africa

\section{KEYWORDS:}

green economy; innovation; South Africa; policy; development

\section{HOW TO CITE:}

Diab R. State of green

technologies in South Africa. S Afr J Sci. 2015;111(3/4), Art. \#a0102, 1 page. http://dx.doi. org/10.17159/sajs.2015/a0102

\footnotetext{
(C) 2015. The Author(s). Published under a Creative Commons Attribution Licence.
}

'There can be no green economy without green technologies and technological innovation'1(p.31). Could this perhaps be the quintessential message conveyed in the recently published Academy of Science of South Africa (ASSAf) report The State of Green Technologies in South Africa?

The promise of the green economy surrounds us. Internationally, we have the United Nations Environment Programme's report titled Towards a Green Economy², published in 2011; the Organisation for Economic Cooperation and Development's 2011 report Towards Green Growth ${ }^{3}$; and the World Bank's report Inclusive Green Growth $^{4}$, published in 2012. And, as the ASSAf report shows, there is no shortage of South African policy documents that support the notion of the green economy - the New Growth Path ${ }^{5}$, the National Development Plan ${ }^{6}$ and the Green Economy Accord ${ }^{7}$, to name but a few.

The green economy is a seductive notion - it presents a positive and optimistic view of a better and more sustainable future. It promises a cleaner environment, a solution for climate change problems, and, perhaps most important of all, the creation of new green jobs.

We are pinning so many of our hopes and aspirations on a transition to a green economy, but no country seems to have yet achieved that transformation. Is the green economy destined to be an aspiration for a better future that continues to elude us, or could green technologies be the key to unlock this transitional inertia?

If the byline quoted above - 'there can be no green economy without green technologies and technological innovation', which was originally attributed to Gisbert Glaser - is to be believed, then the report The State of Green Technologies in South Africa is poised to play a pivotal role in South Africa's transition to a green economy. The report systematically unpacks the state of green technologies, identifying opportunities sector by sector. However, given that technology is advancing so rapidly, this review is not where the report's real value lies. There are many more strategic and fundamental guidelines for policymakers; some of these guidelines are included in the recommendations at the end of the report, while others lie embedded in the report, and require a careful read.

The recommendation that there should be policy coherence and policy coordination is not a surprising one and provides an opportunity for the Department of Science and Technology (DST) to take a lead in bringing relevant government departments to the table to give effect to this recommendation. The nudge towards a 'developer role' for South Africa, rather than just an 'implementer role', is interesting. It is argued that local innovation and manufacturing should be the ultimate goal, emphasising the importance of a robust National System of Innovation (NSI) and investment in research and development (R\&D) and skills development. Again this recommendation speaks directly to the DST as custodian of the NSI and the development of appropriate human capital. If one follows the logic, it is basically saying that investment in R\&D is a prerequisite for a green technologies thrust and, by implication, a transition to the green economy.

There is a thoughtful chapter on the role of business which provides a useful starting point for a much-needed conversation between government and the private sector on how to cooperate in the green technology space.

The recommendation for systematic evaluations of failed or discontinued projects is one that is applicable very broadly. Too often, failed projects are never scrutinised to boost learning experiences but findings are rather kept under wraps. There should be no embarrassment in failure provided one learns and does better the next time. It is argued in the report that because many green technologies are at an early developmental stage, they are more likely to pose risks and be potential failures - a situation which is not to be feared but rather welcomed, as through the conduct of systematic assessments an opportunity to improve and progress is presented.

Finally, there are some all-important messages that touch on human behaviour. One can have all the innovation in the world, but ultimately, technologies have to be adopted by users. Some reasons for the failure of people to adopt technologies are unpacked. Adoption is described as a process that takes time and requires intervention. The power of the media, both traditional and social, early adoption by celebrities and the role of government incentives are stressed.

This report is not one in which responsibility for implementation of recommendations rests with a particular government department. It is relevant for many, as well as industry, the non-governmental organisation sector and the private citizen. Ultimately, each of us has a role to play in ensuring that the green economy becomes a reality and not simply an aspiration.

\section{References}

1. Academy of Science of South Africa (ASSAf). The state of green technologies in South Africa. Pretoria: ASSAf; 2014. Available from: http://www.assaf.co.za/wp-content/uploads/2015/01/8-Jan-2015-WEB-526305-ASSAF-Green-Tech-mail.pdf

2. United Nations Environment Programme (UNEP). Towards a green economy: Pathways to sustainable development and poverty eradication. Nairobi: UNEP; 2011. Available from: http://www.unep.org/greeneconomy/Portals/88/documents/ger/ ger_final_dec_2011/Green\%20EconomyReport_Final_Dec2011.pdf

3. Organisation for Economic Co-operation and Development (OECD). Towards green growth [document on the Internet]. c2011 [cited 2015 Mar 03]. Available from: http://www.oecd.org/greengrowth/48224539.pdf

4. World Bank. Inclusive green growth: The pathway to sustainable development. Washington DC: World Bank; 2012. http://dx.doi. org/10.1596/978-0-8213-9551-6

5. Economic Development Department of South Africa. The new growth path: The framework [document on the Internet]. c2010 [cited 2013 Dec 06]. Available from: http://www.economic.gov.za/communications/51-publications/151-the-new-growth-path-framework

6. National Planning Committee (NPC). National development plan 2030: Our future - Make it work [document on the Internet]. c2011 [cited 2013 Dec 06]. Available from: http://www.gov.za/documents/national-development-plan-2030-our-futuremake-it-work

7. Economic Development Department of South Africa. New growth path: Accord 4 - Green economy accord [document on the Internet]. c2011 [updated 2013 May 14; cited 2013 Dec 06]. Available from: http://www.economic.gov.za/communications/ publications/new-growth-path-series/123-accord-4-green-economy-accordseries/123-accord-4-green-economy-accord 